\title{
POLA KEBERAGAMAAN MASYARAKAT MARGINAL
}

\author{
Ahmad Muttaqin \\ Direktur Pusat Studi Agama dan Kebudayaan STAIN Purwokerto
}

\begin{abstract}
This is a research on sociology of religion, focusing on the issue of religious practices in a local community. Kampung Laut was chosen as the setting of this research for two reasons. First, the rituals of religion practices in the region are different from mainstream practices, which result in label and justification that their religiosity is not a part of or only a fragment of the mainstream religion and tend to be the target of correction. Second, this region raises conflicts among government institutions in relation to the rights of natural resources possession and utilization. The bad image built through this marginalization has formed Kampung Laut community as the one that is resistant and latent. This research used descriptive qualitative method with sociological approach. Rituals of religious practices that are different from the mainstream are explained on the basis of Weber's theory of behavior categorized into value-oriented rationality. This kind of practices is considered to be more beneficial in the context of struggling for identity among the practices of marginalization experienced by Kampung Laut community. This condition gives a description to public that Kampung Laut community receives unfair treatments for their natural resources. Religious issues is made an entry for its massive, communal, and related to transcendental values.
\end{abstract}

Keywords: Religion, Conflict, Ritual, Mainstream.

Abstrak: Penelitian sosiologi agama ini menempatkan isu praktik agama pada komunitas lokal. Kampung Laut dipilih sebagai lokasi penelitian karena dua pertimbangan. Pertama, praktik agama dalam bentuk ritual di Kampung Laut berbeda dengan mainstream. Implikasinya kemudian adalah labelisasi dan justifikasi bahwa keagamaan masyarakat Kampung Laut dianggap tidak menjadi bagian atau setidaknya menjadi sempalan dari agama mainstream sebagai induknya. Kedua, karakteristik khas masyarakat Kampung Laut yang berada dalam pusaran konflik lembaga-lembaga pemerintah atas klaim kepemilikan sumberdaya alam. Citra buruk yang dibentuk melalui proses marginalisasi ini kemudian membentuk karakter khas masyarakat Kampung Laut sebagai komunitas yang resisten dan laten. Tindakan-tindakan yang diarahkan kepada pihak lain di luar komunitasnya diarahkan untuk memperjuangkan eksistensi identitasnya melalui tindakan-tindakan yang terkesan berbeda bahkan menyimpang dengan pandangan masyarakat umum, termasuk dalam hal keberagamaan. Metode yang digunakan dalam penelitian ini adalah kualitatif deskriptif dengan pendekatan sosiologi. Melalui analisis sosiologis, praktik ritual keagamaan yang terkesan berbeda memiliki rasionalisasi yang berdasar teori tindakan Weber dalam kategori rasionalitas berorientasi nilai. Tindakan lokal ini memberi penggambaran kepada masyarakat umum bahwa ma- 
syarakat Kampung Laut mengalami perlakuan tidak adil atas sumberdaya yang diperebutkan. Agama menjadi titik masuk isu ini mengingat sifatnya yang massif, komunal, dan termobilisasi oleh nilai-nilai transendental.

Kata-Kata Kunci: Agama, Konflik, Ritual, Mainstream.

\section{PENDAHULUAN}

Secara sosiologis, agama muncul pada saat ilmu pengetahuan dan teknologi sebagai kekuatan yang diandalkan untuk memenuhi kebutuhan hidup mengalami degradasi atau kehilangan kemampuannya. Manusia hidup dihadapkan pada kondisi alam dan lingkungan sosial yang harus diubah agar memberi kontribusi atau minimalnya tidak memberi ancaman bagi kelangsungan kehidupan. Proses mengubah alam dan lingkungan sosial ini dilakukan dengan pendekatan ilmu pengetahuan dan teknologi yang bersifat empiris dan teknis. ${ }^{1}$

Pada saat manusia mengalami ketidakberdayaan akibat ketidakmampuan ilmu pengetahuan dan teknologi, muncul keyakinan bahwa selain yang empiris terdapat sesuatu yang non-empiris. Seuatu yang non-empiris ini diyakini memiliki kontribusi dan memberikan pengaruh bagi kehidupan manusia di bumi. Dalam konteks inilah muncul kebutuhan baru manusia untuk mengetahui dan berinteraksi dengan kehidupan non-empiris untuk memberikan jaminan agar kehidupan tetap berlangsung dan sejahtera. Proses mengetahui dan berkomunikasi dengan sesatu yang non-empiris ini yang kemudian disebut dengan agama. ${ }^{2}$

Dengan pola di atas, agama merupakan bentuk universal yang dihadapi manusia di belahan bumi manapun. Artinya, bahwa agama muncul dan menjadi kebutuhan baru manusia yang gejalanya bersifat dinamis dan terus berubah. Semakin suatu masyarakat dinamis dan berkembang maka kebutuhan akan sesuatu yang bersifat transendental dalam rangka mengelola hal-hal yang non-empiris semakin tinggi. Persoalan yang kemudian muncul adalah formulasi dan konstruksi keyakinan keagamaan yang berbeda-beda. Perbedaan ini terjadi terutama karena proses pewarisan keyakinan secara turun-temurun. Hal lain yang berpengaruh terhadap konstruksi yang berbeda tentang agama adalah pandangan sosial suatu komunitas atas lingkungan alam dan sosial yang mengitarinya.

\section{KONSTRUKSI AGAMA}

Agama muncul dalam ruang sosial yang dinamis dan memiliki kelenturan atau fluiditas pada saat berinteraksi dengan unsur-unsur lain sebagai salah satu bagian dari proses sosial yang berlangsung. Bahkan pada 
beberapa kasus, proses fluiditas berdampak pada pemaknaan baru suatu entitas yang berinteraksi. Agama sebagai entitas yang memiliki makna khusus bisa bermakna baru yang berbeda dengan sebelumnya ketika berinteraksi dengan kebudayaan lain. ${ }^{3}$ Makna baru ini kemudian dijadikan sebagai konsensus dan referensi baru suatu komunitas pembentuknya dan mendorong perilaku-perilaku yang berbeda dengan mainstream agama sebelum mengalami fluiditas.

Usia agama yang telah berabad-abad seiring sejarah manusia di bumi menjadikannya mengalami evolusi dalam banyak tahap. ${ }^{4}$ Ini artinya bahwa agama sebagi konstruksi tidak bersifat ajeg, tetapi mengalami dinamika seiring dengan perubahan yang terjadi di masyarakat. Persoalannya kemudian adalah agama terutama yang bersumber pada ajaran-ajaran samawi (Islam, Nasrani, dan Yahudi) diyakini memiliki kebenaran tunggal. Keyakinan kebenaran tunggal ini kemudian mendorong sekelompok komunitas mengkonstruksi agama sebagai mainstream. Melalui proses-proses kajian metodologis, beberapa komunitas mengklaim pemahaman tentang agama yang diyakini sebagai yang benar sehingga harus menjadi mainstream bagi pemahaman kelompok lain. Dalam situasi inilah agama berubah menjadi area kontes dan perebutan klaim-klaim kebenaran.

Secara sosiologis agama merupakan manifestasi kebutuhan manusia atas persoalan-persoalan yang tidak bisa dipecahkan secara empiris dan teknologis. Agama kemudian memberi keyakinan baru berupa spiritualitas kepada manusia dan mendasari perilaku dan tindakan-tindakan baru dalam mengubah lingkungan alam dan sosial.5 Perbedaan geografis, ekonomi, sosial, dan politik menjadikan masyarakat terklasifikasi dalam komunitaskomunitas sosial yang berbeda. Perbedaan ini sekaligus menjadi titik awal pandangan suatu komunitas terhadap segala sesuatu, termasuk agama.

Keberadaan lingkungan alam dan sosial memberi pengaruh besar terhadap konstruksi pikir komunitas atas sesuatu. Lingkungan alam dan sosial yang keras misalnya akan memberi pengaruh terhadap cara berpikir seseorang atau komunitas daerah tersebut yang lebih bercorak resisten atau atau protektif. Adapun komunitas lain yang kondisi alam dan sosialnya lebih modern akan memberi pengaruh yang cenderung soft dan adaptif. Pengaruh ini berdampak pada konstruksi agama sebagai kayakinan yang muncul dan menjadi keniscayaan bagi kelompok-kelompok sosial yang berinteraksi secara dinamis.

Secara stratifikatif, pandangan tentang agama antarkelas-kelas sosial berbeda. Pandangan ini sejalan dengan kepentingan sosial (social interest) masing-masing kelas yang berbeda. Kelas sosial yang relatif berposisi 
menengah ke atas akan memiliki pandangan bahwa agama sebagai entitas yang dimiliki oleh setiap kelompok sosial merupakan aset ekonomis yang bisa dimanfaatkan dalam rangka memperoleh keuntungan. Sebaliknya, bagi kelas sosial yang berposisi menengah ke bawah, agama dianggap sebagai representasi kekuatan yang mampu mengakomodasi kelemahankelemahan yang dimilikinya. Melalui agama, kelompok sosial ini menutupi kelemahan-kelemahan tersebut melalui tindakan-tindakan peribadatan dan ritual keagamaan lainnya. ${ }^{6}$

Persoalan kemudian adalah stratifikasi sosial terbentuk secara sosial. Artinya, bahwa pelapisan sosial yang ada terjadi melalui proses-proses sosial yang mengarah pada praktik-praktik kekuasaan. Relasi kuasa yang timpang kemudian melahirkan kelompok-kelompok sosial berkuasa-dominan dan kelompok-kelompok sosial marginal-tidak berdaya. Stratifikasi sosial mewakili praktik kepentingan (interest) yang berbeda dari masing-masing anggotanya. Kelompok dominan akan menempati posisi lapisan sosial yang paling atas, sedang kelompok sosial subordinat akan diposisikan pada lapisan yang rendah. ${ }^{7}$

Pada saat stratifikasi ini telah terbentuk, secara sosiologis akan memunculkan cara pandang unik yang dikembangkan oleh masing-masing kelompok dalam memandang sesuatu. Cara pandang ini disesuaikan dengan kepentingan politik (political interest) yang dimiliki dan diarahkan untuk membantu komunitas mencapai tujuan-tujuan tertentu.

Oleh karena stratifikasi terbentuk secara sosial maka realitas yang terjadi pada proses pelapisan sosial adalah praktik politik. Kelompok dominan akan mendorong kelompok yang didominasi keluar dari lingkaran sosialnya dan menjadi aset bagi objek-objek kekuasaan dan dominasinya. Proses ini kemudian disebut dengan marginalisasi. ${ }^{8}$ Artinya adalah kelompok dominan secara ekonomi, kekuasaan, pengetahuan, dan kehormatan akan mendorong kelompok tertentu lainnya untuk menempati posisi sosial yang bersifat hierarkis berada di bawahnya. Dengan menempati posisi sosial di bawahnya, kelompok dominan ini memiliki klaim politik atas kelompok tersebut dan memiliki kekuasaan untuk mengembangkan relasi-relasi kuasa yang timpang.

Sementara itu, kelompok marginal secara evolutif mengembangkan cara berpikir sendiri sebagai bagian dari upaya membangun karakter dan identitas diri. Cara berpikir ini dikembangkan berdasar realitas marginalisasi yang diterima sehingga cenderung reaktif. Pada tahap lanjut, cara berpikir ini akan menjadi panduan (guidance) bagi komunitas dan anggotanya dalam bertindak dan berperilaku yang umumnya berbeda dengan main- 
stream. Agama dalam masyarakat Indonesia dijadikan sebagai panduan moral dalam bertindak dan berperilaku yang bersifat universal sehingga muncul bentuk-bentuk tertentu sebagai mainstream. Bagi kelompok marginal, agama dalam bentuk mainstream adalah bentuk dominasi tertentu sehingga mereka mengembangkan cara berpikir sendiri tentang agama yang dijadikan sebagai panduan bertindak dan berperilaku anggotanya.

\section{KOMUNITAS KAMPUNG LAUT}

Kampung Laut secara geografis berada di wilayah Kabupaten Cilacap yang berdampingan langsung dengan Pulau Nusakambangan. Kampung Laut merupakan kecamatan hasil pemekaran dari Kawunganten memiliki 4 (empat) desa, yaitu Ujung Gagak, Klaces, Ujung Alang, dan Panikel. Masing-masing desa terpisah oleh perairan sehingga transportasi satu desa dengan desa lainnya menggunakan kapal atau perahu.

Persoalan mendasar yang dialami masyarakat Kampung Laut saat ini adalah pendangkalan Segara Anakan akibat laju sedimentasi dari beberapa sungai terutama Citanduy dan Cimeneng. Sementara itu, Segara Anakan merupakan area tangkap ikan masyarakat Kampung Laut. Dengan semakin dangkalnya Segara Anakan maka matapencaharian masyarakat sebagai nelayan tangkap tradisional terancam.

Secara sosial, masyarakat Kampung Laut hidup dalam pusaran konflik yang melibatkan tiga institusi besar negara, yaitu Kehakiman sebagai lembaga yang memiliki otoritas Pulau Nusakambangan, Perhutani sebagai pengelola hutan sekitar Nusakambangan, dan Pemerintah Daerah sebagai penguasa wilayah. ${ }^{9}$ Konflik yang melibatkan lembaga-lembaga tersebut sudah berlangsung lama dan hingga kini belum ada penyelesaian sehingga masyarakat menjadi pihak yang paling banyak menanggung dampaknya.

Keberadaan masyarakat Kampung Laut dalam pusaran konflik diposisikan sebagai kelompok yang salah, ilegal, dan liar membentuk karakteristik baru sebagai reaksi atas proses marginalisasi. Proses yang berlangsung lama kemudian membentuk pandangan umum masyarakat Kampung Laut tentang kediriannya sebagai kelompok yang didominasi, dikuasasi, dan ditindas. Situasi inilah yang mendorong secara kolektif untuk menolak proses sosial yang ada melalui pembentukan perilaku dan tindakan-tindakan yang anti mainstream.

Perilaku dan tindakan ini diambil karena masyarakat Kampung Laut yang dimarginalisasi secara sosial, ekonomi, dan budaya menganggap bahwa segala bentuk yang bersifat mainstream adalah manifestasi kekuasaan dominatif. Oleh karena itu, sebagai bentuk penolakan masyarakat 
kemudian melakukan perilaku dan tindakan yang berbeda dengan arus besar sebagai seuatu yang unik, bersifat lokal, dan parsial. Termasuk dalam konteks ini adalah agama.

Sebagai entitas universal, keberadaan agama secara substantif tidak bisa ditolak oleh masyarakat Kampung Laut. Namun secara sosial politik, konstruksi agama sebagai mainstream ditolak. Masyarakat memiliki konstruksi sendiri tentang agama yang didasarkan atas kondisi lingkungan alam dan sosial yang secara umum memposisikan mereka sebagai kelompok marginal. Dalam konteks inilah penelitian ini dirancang untuk menemukan pandangan-pandangan keagamaan masyarakat Kampung Laut. Pandangan keagamaan ini yang berfungsi sebagai panduan masyarakat bertindak dan berperilaku secara sosial.

\section{TEORI TINDAKAN SOSIAL}

Tindakan sosial bagi Weber adalah suatu tindakan individu sepanjang tindakan itu mempunyai makna atau arti subjektif bagi dirinya dan diarahkan kepada tindakan orang lain..$^{10}$ Suatu tindakan individu yang diarahkan kepada benda mati tidak masuk dalam kategori tindakan sosial. Tindakan sosial merupakan tindakan yang nyata-nyata diarahkan kepada orang lain. Tindakan sosial dapat berupa tindakan yang bersifat membatin atau bersifat subjektif yang mungkin terjadi karena pengaruh positif dari situasi tertentu atau merupakan tindakan perulangan dengan sengaja sebagai akibat dari pengaruh situasi yang serupa atau berupa persetujuan secara pasif dalam situasi tertentu. ${ }^{11}$

Jelasnya ada lima ciri pokok yang menurut Weber ${ }^{12}$ termasuk sebagai tindakan sosial, yaitu: (1) jika tindakan manusia itu menurut aktornya mengandung makna subjektif dan hal ini bisa meliputi berbagai tindakan nyata; (2) tindakan nyata itu bisa bersifat membatin sepenuhnya; (3) tindakan itu bisa berasal dari akibat pengaruh positif atas suatu situasi, tindakan yang sengaja diulang, atau tindakan dalam bentuk persetujuan secara diam-diam dari pihak manapun; (4) tindakan itu diarahkan kepada seseorang atau kepada beberapa individu; dan (5) tindakan itu memperhatikan tindakan orang lain dan terarah kepada orang lain itu. Selain kelima ciri pokok tersebut, menurut Weber tindakan sosial dapat pula dibedakan dari sudut waktu sehingga ada tindakan yang diarahkan kepada waktu sekarang, waktu lalu, atau waktu yang akan datang. Sasaran suatu tindakan sosial bisa individu tetapi juga bisa kelompok atau sekumpulan orang.

Lebih detilnya, konsepsi tindakan sosial Max Weber adalah tindakan manusia yang dapat mempengaruhi individu-individu lainnya dalam ma- 
syarakat serta mempunyai maksud tertentu. Suatu tindakan sosial adalah tindakan yang dilakukan dengan mempertimbangkan perilaku orang lain dan berorientasi pada perilaku orang lain. ${ }^{13}$

Teori tindakan sosial terbagi dalam empat tipe, yakni tindakan rasional instrumental, tindakan rasional berorientasi nilai, tindakan tradisional, dan tindakan afektif. Tindakan rasional instrumental merupakan tindakan yang dilakukan oleh seseorang dengan memperhitungkan kesesuaian antara cara yang digunakan dengan yang dipikirkan. Pelaku berpikir bahwa tindakan yang dilakukan termasuk dalam kriteria baik dan benar menurut ukuran dan penilaian masyarakat di sekitarnya. Contohnya, seseorang ingin membeli kendaraan bermotor. Ia harus bekerja keras untuk mengumpulkan uang. Uang tersebut disisihkan untuk keperluan pribadi dan tabungan membeli kendaraan. Jika tabungannya sudah terkumpul atau sudah mencukupi harga sebuah kendaraan bermotor, maka ia akan membeli kendaraan tersebut.

Tindakan tradisional merupakan tindakan yang tidak rasional karena seseorang melakukan tindakan hanya karena kebiasaan yang berlaku dalam masyarakat tanpa menyadari alasannya atau membuat perencanaan terlebih dahulu mengenai tujuan-tujuan yang akan dicapai oleh sang aktor. Jadi, tindakan tradisional berdasarkan suatu nilai yang hanya mengikuti pada tradisi yang dilakukan dan hanya berdasarkan oleh para pendahulunya saja, tidak diketahui apa maksud dan tujuan dari kegiatan tersebut. Tindakan ini bahkan tidak rasional untuk dilaksanakan. Contohnya adalah upacara adat Jawa yang sudah ada semenjak zaman dahulu. Kadang tujuannya bahkan tidak diketahui oleh yang melaksanakan.

Tindakan rasional berorientasi nilai merupakan tindakan yang bersifat rasional dan memperhitungkan manfaatnya, tetapi tujuan yang hendak dicapai dan cara yang digunakan tidak terlalu dipentingkan. Jadi, rasional berorientasikan nilai adalah tindakan sosial yang memperhitungkan manfaatnya, tapi tujuan yang ingin dicapai tidak terlalu dipertimbangkan. Tindakan tersebut dinilai baik dan benar oleh masyarakat sekitarnya. Contohnya yaitu seseorang yang melakukan ibadah sesuai dengan agamanya masing-masing. Contoh lainnya yaitu seorang pemuda memberikan tempat duduknya kepada seorang nenek karena ia memiliki keyakinan bahwa anak muda harus hormat kepada orang tua. Atau, seorang berpuasa sekian hari untuk mendapatkan berkah sesuai dengan kepercayaannya.

Tindakan afektif merupakan tindakan yang biasanya dikuasai oleh perasaan atau emosi tanpa memperhitungkan akal budi. Seringkali tindakan ini dilakukan tanpa perencanaan matang dan tanpa kesadaran penuh 
dan dapat dikatakan tindakan yang dilakukan merupakan reaksi spontan atas suatu peristiwa. Tindakan ini juga bersifat irasional. Contohnya adalah seseorang bekerja lebih giat untuk mendapatkan pujian dari atasannya. Tindakan ini didasarkan pada perasaan yang ingin mendapat perhatian lebih. Contoh lainnya, orang tua akan melakukan apa saja untuk melindungi anaknya, bahkan melakukan hal yang dapat membahayakan dirinya sendiri untuk menyelamatkan anaknya. Tindakan afektif terhadap si anak, membuat orangtua tersebut melakukan hal yang orang lain tidak bersedia lakukan.

Tindakan sosial menekankan pada orientasi subjektif yang mengendalikan pilihan-pilihan individu. Pilihan-pilihan ini secara normatif diatur atau dikendalikan oleh nilai atau standar normatif bersama. Hal ini berlaku untuk tujuan-tujuan yang ditentukan individu serta alat-alat yang digunakan untuk mencapai tujuan-tujuan itu juga dalam memenuhi kebutuhan fisik yang mendasar ada pengaturan normatifnya. ${ }^{14}$

\section{MARGINALISASI SEBAGAI PRAKTIK POLITIK}

Istilah marginalisasi banyak digunakan dalam disiplin ilmu komunikasi kritis. Ia menunjuk pada bentuk konsep representasi yang disalahkan atau misrepresentasi. ${ }^{15}$ Dalam marginalisasi terjadi penggambaran buruk dari pihak lain. Tujuannya adalah melakukan konstruksi opini atas pihakpihak tertentu agar mendapat penilaian yang buruk sehingga menimbulkan reaksi-reaksi yang negatif. Praktik marginalisasi umum digunakan dalam pemberitaan media massa melalui penggunaan dan pilihan kata yang berkonotasi negatif terhadap objek pemberitaan.

Dalam pengertian di atas, marginalisasi merupakan praktik politik yang dilakukan secara sengaja oleh pihak tertentu terhadap pihak lain dengan tujuan menempatkannya pada posisi yang tidak menguntungkan. Artinya, kelompok sasaran praktik marginalisasi sengaja ditempatkan pada sebuah posisi yang memungkinkan setiap orang atau kelompok berpikir negatif atas mereka. Melalui konstruk berpikir negatif inilah, kelompok yang dimarginalisasi terpinggir dalam praktik sosial, politik, dan budaya yang berlangsung dalam masyarakat umum.

Melalui marginalisasi ini, segala sesuatu yang berasal kelompok sasaran dianggap buruk dan berpotensi memberikan kontribusi negatif atas proses-proses sosial yang berlangsung. Dengan anggapan ini maka tindakan dan perilaku kelompok marginal dianggap tidak bermakna atau bahkan harus dihindari agar ekses-ekses negatif yang mungkin ditimbulkannya bisa diantisipasi. Bahkan perilaku yang sesungguhnya bernuansa positif 
bisa dianggap buruk melalui penggambaran-penggambaran yang tidak sesuai dengan fakta sesungguhnya. ${ }^{16}$

Selain sebagai praktik politik, marginalisasi juga bisa berlangsung dalam beberapa kondisi. Pertama, situasi lingkungan fisik dan sosial yang menempatkan seseorang atau kelompok berbeda dengan komunitas umum lainnya. Keberbedaan lingkungan fisik dan sosial ini kemudian melahirkan praktik-praktik sosial, politik, dan budaya yang berbeda dengan praktik mainstream dalam masyarakat. Oleh karena bersifat diferentiatif maka pelaku-pelaku praktik sosial tersebut dianggap marginal. ${ }^{17}$

Kedua, sikap sosial yang berbeda dengan umumnya masyarakat. Secara fungsional, sikap sosial sesungguhnya dipengaruhi oleh proses interaksi yang berlangsung. ${ }^{18}$ Apabila proses interaksi yang terjadi mengarah pada bentuk respon-respon yang berkonotasi negatif maka sikap sosial yang diambil lebih bersifat resisten. Melalui pengertian ini sikap sosial sesungguhnya bersifat konstruktif dari proses-proses sosial yang berlangsung.

Ketiga, pola perilaku yang didasarkan atas referensi-referensi reaktif atas situasi lingkungan fisik dan sosial. Kondisi ini berbeda dengan umumnya yang pola sosialnya terbentuk melalui internalisasi nilai-nilai yang didasarkan atas pengalaman-pengalaman formal. ${ }^{19}$ Prosesnya berlangsung secara transformatif sehingga tidak mengakibatkan distabilitas dalam masyarakat. Pola perilaku yang bersifat reaktif umumnya melahirkan bentukbentuk resistensi yang mengarah pada sikap-sikap eksklusif atas potensi interaksi yang terjadi. Dalam pola ini, referensi reaktif bernuansa revivalis dalam arti menganggap segala hal baru yang datang berpotensi memberikan ancaman. Oleh karena pandangan ini maka proses transformasi yang minim menimbulkan gejolak sosial sulit terjadi. Perubahan-perubahan yang terjadi bersifat konfliktual dan mengarah pada pembentukan tindakantindakan yang konfliktual.

\section{KONDISI SOSIOLOGIS MASYARAKAT MARGINAL}

Kelompok marginal atau pinggiran memiliki konstruksi sosiologis yang berbeda dengan kelompok sosial umumnya. Hal ini karena unsur pembentuk sosiologis kelompok marginal umumnya berasal dari luar dirinya yang prosesnya berlangsung secara politis. Artinya adalah bahwa keberadaan kelompok marginal bukan merupakan sesuatu yang bersifat alamiah, tetapi merupakan produk sosial yang prosesnya berlangsung secara politis dan didasarkan atas relasi kuasa yang tidak berimbang. ${ }^{20}$

Dalam konteks perilaku sosial, teori interaksionisme simbolik mengasumsikan bahwa semua tindakan manusia didasarkan atas makna yang 
dikandung oleh benda atau barang yang menjadi sasarannya. Makna tersebut ditentukan melalui konsensus bersama yang lalu memunculkan simbol-simbol tertentu. Melalui simbol ini, individu dan kelompok saling berinteraksi satu sama lainnya. Melalui pola ini sesungguhnya setiap tindakan manusia memiliki makna tertentu dan proses produksinya melibatkan pengetahuan-pengetahuan yang dimiliki komunitas di mana individu berinteraksi.

Unsur pembentuk perilaku pada masyarakat marginal dimaknai secara konsensus oleh anggota-anggota kelompoknya. Proses pemaknaan didasarkan atas pandangan dunia (world view) kelompok yang dipengaruhi oleh situasi kognitif sebagai aspek psikologis. Situasi kognitif dikreasikan melalui aktivitas mental yang dibentuk berdasar kondisi-kondisi sosiologis sekitarnya. Kondisi sekitar bersifat politis dan alamiah yang secara kolaboratif membentuk kekhasan perilaku dan tindakan-tindakan sosialnya. Perilaku dan tindakan sosial merupakan aspek eksoteris yang bersifat empiris. Aspek ini didasarkan atas aspek mental atau kognitif yang proses pembentuknya melibatkan situasi-situasi sosiologis sekitar.

Dalam konteks masyarakat marginal, perilaku dan tindakan hanya bisa dimaknai secara menyeluruh dan total dari kesatuan aktivitas mental dan empiris. Pola pikir masyarakat marginal dipengaruhi oleh situasisituasi psikososial yang memposisikannya berperilaku di luar mainstream. Perilaku ini yang sering diistilahkan dengan tidak beradab dan tidak beretika. Labelisasi ini berlangsung terus-menerus sehingga menjadi salah satu pembentuk karakter yang cukup berpengaruh bagi kelompok marginal.

Proses marginalisasi ini kemudian berpengaruh signifikan bagi terciptanya kondisi-kondisi sosial kelompok yang diposisikan terpinggir. Pertama, konfliktual. ${ }^{21}$ Marginalisasi sebagai praktik politik mengarah kepada pembentukan sosial yang berbeda dengan gambaran aslinya. Tujuan marginalisasi adalah memberi penggambaran yang tidak sesuai yang umumnya berkonotasi buruk atas kelompok masyarakat yang menjadi target sasaran. Proses ini kemudian melahirkan kondisi-kondisi khas masyarakat marginal yang berasal dari kontroversi internal. Dalam tingkat lanjut, kontroversi ini kemudian memunculkan sikap-sikap curiga dan ketidakpercayaan yang dimiliki oleh masing-masing individu anggota masyarakat. Sikap penuh curiga dan underestimate pada tahap lanjut menjadi embrio bagi hubungan-hubungan sosial yang terpola secara konfliktual.

Masyarakat marginal terkondisikan untuk mengembangkan pola-pola interaktif yang bersifat konfliktual. Kelompok sosial yang berada di luarnya dianggap sebagai liyan (the others) yang keberadaannya memberikan po- 
tensi bagi eksistensi kelompok sosial yang dikategorikan sebagai marginal. Namun demikian, pola sosial yang konfliktual ini sesungguhnya hanya sebagai titik masuk (entry point) bagi proses interaksi berikutnya. Artinya bahwa pola konfliktual sebagai karakter permukaan kelompok marginal dalam hubungannya dengan interaksi terhadap kelompok-kelompok yang dianggap berada di luar komunitasnya. Sebagai proses awal interaktif, pola konfliktual bersifat transisional yang sementara dan akan menjadi permanen saat terjadi keseimbangan melalui proses interaksi berikutnya. ${ }^{22}$

Kedua, resisten dan cenderung eksklusif. Penggambaran buruk dalam proses marginalisasi berkembang menjadi kebenaran umum (common sense) yang diakui oleh masyarakat. Secara alamiah, masyarakat akan mengidentifikasi perilaku-perilaku tertentu yang umumnya berkonotasi negatif terhadap kelompok-kelompok yang menjadi sasaran marginalisasi. Kecenderungan common sense ini kemudian memunculkan respon sosial dan politik dari kelompok yang dimarginalisasi melalui sikap-sikap resisten dan kecenderungan berperilaku eksklusif.

Sikap resisten kelompok marginal diarahkan untuk memberi pernyataan ketidaksetujuan atas common sense yang berlangsung. Artinya, resistensi ini diarahkan untuk melakukan counter atas konstruksi, isu, dan asumsi-asumsi yang dikembangkan oleh pihak tertentu yang dijadikan referensi oleh publik untuk membentuk common sense. Sikap resisten ini kemudian diperkuat dengan pilihan perilaku eksklusif dalam arti meminimalisasi pengaruh-pengaruh dan keterlibatan kelompok yang dianggap the others dalam proses sosial internal kelompok marginal.

Ketiga, agresif dalam memproduksi tindakan-tindakan massal yang bersifat komunal. Tindakan ini didasarkan atas kesadaran bahwa kelompok marginal adalah korban dari proses politik yang dominatif. Artinya, label, karakter, dan simbol yang melekat kepada mereka bukan berasal dari produksi dan reproduksi sosial kelompok yang bersifat genuine. Sebaliknya, segala atribut yang melekat adalah pemberian dari kelompok tertentu yang memiliki kepentingan tertentu atas keterpinggiran kelompok sasaran marginalisasi. Melalui kesadaran ini, kelompok marginal kemudian melakukan perlawanan melalui produksi tindakan-tindakan massal-komunal yang diarahkan memberi penyeimbang atas proses politik sosial yang berlangsung. Gerakan komunal ini umumnya dieskalasi melalui perilaku-perilaku agresif dalam rangka memberikan efek sosial yang tinggi.

Tindakan agresif secara sosiologis ditemukan pada jenis-jenis yang kontroversial atau dianggap menyimpang, misalnya pendudukan, demonstrasi, atau kegiatan-kegiatan yang memiliki kesan destruktif. Efek tindakan 
agresif ini yang kemudian dijadikan sebagai sarana bagi kelompok marginal untuk menunjukkan eksistensi kepada publik tentang praktik-praktik marginalisasi yang diarahkan kepada mereka sebagai bentuk rekayasa sosial.

Keempat, latensi. Istilah latensi sesungguhnya dihadapkan dengan konsep manifes. Latensi sering digunakan untuk menggambarkan fungsifungsi sosial dalam masyarakat yang muncul tanpa ada proses desain sebelumnya. Setiap peran memiliki 2 (dua) fungsi yang saling berpasangan, yaitu fungsi manifes dan laten. Fungsi manifes adalah manfaat atau kegunaan suatu tindakan atas peran-peran tertentu yang disandang oleh individu atau kelompok. Adapun fungsi manifes adalah manfaat atau dampak yang muncul atas peran tertentu yang tidak diharapkan tetapi keberadaannya tidak bisa ditolak. ${ }^{23}$

\section{MARGINALISASI MASYARAKAT KAMPUNG LAUT}

Keberadaan masyarakat Kampung Laut dimulai jauh sebelum Indonesia dideklarasikan. Tepatnya sekitar abad ke-12, ketika pemerintahan Kerajaan Mataram yang mengutus beberapa prajuritnya untuk mengamankan wilayahnya dari para bajak laut berkebangsaan Portugis. ${ }^{24}$ Sejak saat itu, kehidupan masyarakat Kampung Laut dimulai dan matapencaharian mereka adalah nelayan tradisional dengan area tangkap utamanya di Segara Anakan.

Persoalan kemudian mulai muncul saat pulau Nusakambangan ditetapkan sebagai "Pulau Penjara" oleh pemerintah Hindia Belanda. Pulau yang sebelumnya tidak berpenghuni kemudian kedatangan warga baru, baik para tahanan maupun sipir dan keluarganya. Warga yang tadinya menempati tanah-tanah di Nusakambangan kemudian tergeser ke wilayah-wilayah pinggiran Nusakambangan yang saat ini dikenal dengan Kampung Laut. Konflik semakin meningkat pada saat pemerintah Indonesia menetapkan bahwa Nusakambangan merupakan otoritas dari kehakiman yang diperuntukkan sebagai penjara melalui ordonansi staatblads Pemerintah Hindia Belanda Nomor 25 tanggal 10 Agustus 1912. Staatblads tersebut menetapkan Nusakambangan sebagai Pulau Penjara yang pengelolaannya diserahkan kepada Departemen Van Justitie (Departemen Kehakiman) dan saat ini menjadi Menkum HAM.

Konflik pertama yang muncul adalah pengelola Nusakambangan merasa berhak atas segala yang ada di atas Pulau termasuk lahan-lahan pertanian yang digarap oleh warga Kampung Laut sebagai matapencahariaan. Sikap represif ala militer menjadi intimidasi tersendiri bagi warga untuk meninggalkan lahan pertanian di Pulau Nusakambangan. Konflik 
awal ini tidak berhenti setelah terjadi pengusiran dari Nusakambangan, tetapi justru semakin mengalami peningkatan karena pertanian saat itu merupakan satu-satunya pilihan yang mungkin diambil selain menjadi nelayan tradisional.

Kedua, konflik semakin meningkat saat terjadi perubahan lingkungan fisik berupa pendangkalan Segara Anakan akibat sedimentasi sungai-sungai terutama dari Citanduy dan Cimeneng. Sedimentasi ini berdampak pada meningkatnya tumpukan lumpur di sepanjang aliran sungai dan laguna yang berakibat menyempitnya Segara Anakan. Perubahan fisik ini memaksa warga Kampung Laut berpikir alternatif untuk mencari profesi baru di luar nelayan tradisional. Tumpukan lumpur yang disebut tanah timbul kemudian dimanfaatkan oleh warga sebagai lahan pertanian dan perikanan. Warga mulai beralih profesi dari nelayan tangkap tradisional menjadi petani dan nelayan budidaya. Persoalan kemudian adalah tanah timbul diklaim juga oleh Kehakiman sebagai pemegang otoritas pulau Nusakambangan. Argumentasinya adalah bahwa tanah timbul tersebut menempel pada pulau Nusakambangan sehingga hak penguasaannya berada pada kehakiman. Keberadaan warga kembali terancam oleh otoritas kehakiman.

Ketiga, keberadaan tanah timbul menjadi pusat konflik yang melibatkan institusi besar negara. Selain kehakiman dengan argumentasi bahwa tanah timbul sebagai bagian dari Nusakambangan, muncul dalam pusaran konflik adalah Pemerintah Kabupaten Cilacap dan Perhutani. Masingmasing memberikan argumentasi-argumentasi yang diperkuat dengan landasan regulasi. Pemerintah Kabupaten menggunakan Peraturan Daerah tentang Rencana Tata Ruang Wilayah (RTRW), sementara Perhutani menggunakan PP tentang pengelolaan lahan kritis. Konflik antar institusi negara ini memposisikan warga Kampung Laut sebagai pihak yang dianggap sebagai pelanggar hukum, perambah liar, dan perusak lahan. Ketiganya menempatkan warga sebagai pihak yang salah.

Konflik tiga institusi negara ini sudah berlangsung lama dan hingga kini belum ada titik temu dalam rangka pemecahannya. Kecenderungannya justru dipelihara karena ada kepentingan-kepentingan tertentu atas keberlangsungan konflik. Artinya adalah bahwa konflik di Kampung Laut menjadi komoditas oleh masing-masing institusi tersebut untuk memperoleh keuntungan tertentu. Indikasinya adalah keberadaan proyek-proyek atas nama konservasi, pembinaan, penyelamatan lingkungan, dan berbagai jenis proyek pengentasan kemiskinan.

Keberadaan warga Kampung Laut dalam perspektif konflik di atas menjadi komoditas yang diperebutkan. Situasi sosial warga akan terlihat 
lebih menarik apabila dikonstruksi dalam bentuk atau profil yang deviatif atau diferentiatif dengan masyarakat umum lainnya. Dengan profil warga yang patologis inilah argumentasi-argumentasi tentang pemberdayaan, penyelamatan lingkungan, konservasi, dan penanggulangan kemiskinan diproduksi dan direproduksi. Warga menjadi komoditas yang ditransaksikan melalui proyek-proyek pembangunan.

Dalam konteks mengkonstruksi profil warga yang patologis inilah praktik marginalisasi dilakukan. Isu marginalisasi warga Kampung Laut terpola dalam dua kerangka utama, yaitu perambah liar dan kemiskinan. Isu perambah liar menjadi komoditas oleh Kehakiman, Perhutani, dan Pemkab. Cilacap. Hal ini karena objek yang dijadikan sebagai pusat pengembangan isu perambah liar adalah tanah timbul yang menjadi sumber konflik ketiga lembaga tersebut. Dengan memproduksi isu warga Kampung Laut sebagai perambah liar, masing-masing institusi yang terlibat konflik tersebut memproduksi wacana dan mengkonstruksinya sebagai argumentasi melakukan intervensi dalam rangka melakukan inisiatif pencegahan atau pengurangan praktik-praktik perambahan liar warga.

Dalam formula pencegahan dan pengurangan ini, Kehakiman mengambil isu penegakkan hukum melalui pendekatan represif dan preventif. Pendekatan represif dilakukan dalam bentuk penertiban dan pengambilalihan lahan-lahan produktif warga. Adapun pendekatan preventif dengan bentuk kegiatan pelatihan, pertemuan warga, dan forum-forum rembuk desa. Sementara itu, Perhutani mengambil isu konservasi lingkungan. Perilaku perambahan liar yang dituduhkan kepada Warga Kampung diproduksi sebagai argumentasi Perhutani menyelenggarakan proyek konservasi lingkungan terutama penyelamatan hutan mangrove. Luas tanah timbul yang membentang sepanjang Segara Anakan merupakan potensi yang sangat besar dan menjadi agenda proyek tahunan. Melalui proyek ini, Perhutani memperoleh dana yang besar dari dalam dan luar negeri.

Pemerintah Kabupaten mengambil isu pemberdayaan ekonomi dengan memanfaatkan tanah timbul sebagai area baru ekonomis bagi warga Kampung Laut. Pengambilan isu pemberdayaan ekonomi ini kemudian melahirkan proyek-proyek pelatihan dan peningkatan kapasitas ekonomi produktif berbasis praktik budidaya dan cocok tanam. Anggaran dalam program ini cukup besar dan telah berlangsung sejak tahun 2000. ${ }^{25}$

Isu kedua yang dikembangkan terkait dengan keberadaan warga Kampung Laut adalah kemiskinan. Kehakiman, Perhutani, dan Pemerintah Kabupaten Cilacap memanfaatkan isu kemiskinan dengan usulan kegiatan pembangunan kemitraan. Pola kemitraan adalah memanfaatkan tanah tim- 
bul sebagai area usaha bersama dengan memposisikan warga sebagai penggarap. Namun demikian, program kemitraan ini sekedar wacana karena hingga kini belum ada yang terealisasi. Dugaan ini sangat memungkinkan mengingat wacana kemitraan sudah dimulai sejak tahun 2003.

Proses marginalisasi terhadap warga Kampung Laut berdasarkan narasi di atas terselenggara secara sistematis dan memanfaatkan isu konflik sumberdaya Segara Anakan dan hutan mangrove. Konflik ini sengaja dipelihara dan tidak ada political will dari elite-elite lembaga untuk menyelesaikannya secara tuntas sehingga memberikan kejelasan posisi warga Kampung Laut. Sikap memelihara konflik ini terjadi karena memberikan keuntungan lebih besar bagi masing-masing lembaga melalui proyek-proyek atas nama perambah liar dan kemiskinan warga.

Melalui praktik marginalisasi ini, isu tentang Kampung Laut terkesan kritis, dramatis, dan membutuhkan kecepatan waktu untuk segera ditangani. Konstruksi isu ini kemudian dipertegas dengan pembentukan opini-opini tentang masyarakat Kampung Laut sebagai komunitas yang liar, terbelakang, dan miskin. Dengan demikian, maka marginalisasi Kampung Laut dilakukan secara politis untuk memberikan gambaran-gambaran yang kritis dan memerlukan penanganan ekstra. Lembaga-lembaga yang terlibat konflik semu mengidentifikasikan diri sebagai lembaga yang paling sah untuk diberi kewenangan untuk mengatasi keliaran dan kemiskinan warga Kampung Laut. Sementara itu, warga Kampung Laut sebagai objek marginalisasi diposisikan tidak lebih sebagai partisipan atas proyek-proyek pembangunan yang berlangsung.

\section{POLA TINDAKAN SOSIAL MASYARAKAT KAMPUNG LAUT}

Dalam perspektif Weber, tindakan sosial terpola dalam 4 (empat) bentuk, yaitu tindakan rasional, tindakan tradisional, tindakan rasional berorientasi nilai, dan tindakan afektif. Pada sebuah komunitas, umumnya pola tindakan sosial berlaku salah satu dari bentuk-bentuk yang ada. Hampir tidak ditemukan masyarakat memiliki pola tindakan sosial yang ganda. Hal ini karena tindakan sosial didahului oleh proses berpikir yang secara paradigmatis tersusun dalam diktum-diktum yang bisa diterima secara ideologis.

Dengan demikian, tindakan sesungguhnya merupakan manifestasi konkret dari aktivitas berpikir seseorang atas suatu objek. Tindakan sosial memiliki tingkat koherensi yang tinggi dengan persepsi sosial yang terbentuk. Adapun persepsi itu sendiri, konstruksinya dipengaruhi oleh faktor- 
faktor yang melingkupi seseorang atau kelompok, baik secara fisik maupun sosial. Pada masyarakat marginal, persepsi yang muncul lebih berorientasi terhadap proses-proses yang bersifat resisten atas segala sesuatu yang hadir sebagai hal baru. Persepsi ini terkonstruksi karena secara sosiologis kelompok marginal dikondisikan melalui proses-proses politis dan pengaruh lingkungan fisik yang mendominasi sepanjang kehidupan sosialnya.

Persepsi sosial sebagai basis tindakan sosial kemudian terdistribusi secara konkret melalui tindakan-tindakan sosial yang terkerangka dalam 4 (empat) pola seperti di atas. Substansi persepsi sosial secara kualitatif akan berpengaruh terhadap pilihan pola-pola tindakan sosial yang tersedia. Persepsi sosial pada masyarakat marginal cenderung bersifat resisten dan latensi. Dua karakter sosial ini apabila dilihat dalam perspektif 4 (empat) pola dapat dikualifikasikan pada bentuk rasionalitas berorientasi nilai atau afektif. Kualifikasi ini dilakukan dengan mendasarkan pada bentuk-bentuk khas dari sifat resisten dan latensi yang cenderung mengarah pada bentukbentuk ekspresi emosional sebagai respon yang kurang ekspektatif dari situasi sosiologis yang terjadi.

Karakter latensi masyarakat Kampung Laut terlihat dari bentuk-bentuk yang berbeda dengan kemungkinan tindakan sosial yang mungkin diambil sebagai tindakan formal dan normatif. Tindakan normal dan normatif ini merupakan tindakan yang diharapkan dari fungsi-fungsi sosial yang bersifat manifes. Namun karena karakter sifat latensi, tindakan sosial yang muncul dan dipilih oleh masyarakat Kampung Laut berbeda dengan tindakan manifes yang diharapkan sesuai dengan perspektif mainstream.

Tindakan latensi ini berpola rasionalitas berorientasi nilai. Konservasi hutan mangrove bagi masyarakat Kampung Laut dianggap tidak ada manfaatnya karena pada saatnya akan hilang dengan sendirinya. Kampung Laut menjadi daratan menjadi keniscayaan yang hampir pasti akan terjadi. Maka mempersiapkan untuk memiliki profesi lain di luar sebagai nelayan tradisional tangkap adalah hal yang harus segera dipersiapkan. Memanfaatkan hutan mangrove atau tanah timbul untuk kegiatan budidaya perikanan dan penelusuran jalur sebagai bagian dari eko wisata lebih bernilai ketimbang konservasi penyelamatannya. Dengan demikian, tindakan latensi yang dianggap destruktif dalam perspektif mainstream memiliki rasionalitas yang didasarkan atas nilai-nilai atau manfaat yang dianggap benar oleh komunitas.

Karakter latensi di atas juga dapat dianalisis sebagai tindakan afektif yang merupakan salah satu dari indikasi tindakan kelompok marginal. Dalam perspektif ini, pilihan tindakan yang berbeda dengan ekspektasi 
manifes merupakan tindakan irasional. Artinya, pilihan tindakan masyarakat Kampung Laut membuat tambak perikanan dan jalur ekowisata tidak rasional karena dianggap tidak memberikan kontribusi bagi peningkatan kapasitas hidup komunitas. Perspektif tindakan afektif menunjukkan bahwa tindakan seseorang atau komunitas didasarkan atas perasaan atau emosi tanpa memperhitungkan akal budi. Emosi yang terbangun pada masyarakat marginal adalah terpinggir, dianggap sebagai orang lain (the others), dan berbagai karakter negatif lainnya.

Atas dasar konstruksi emosional ini maka pada saat terjadi mobilisasi tindakan mainstream, masyarakat Kampung Laut sebagai komunitas marginal memilih tindakan-tindakan sosial yang diarahkan dalam rangka membangun solidaritas dan mempertahankan eksistensi kelompok. Tindakan yang berbeda ini tidak akan dilakukan oleh komunitas lain karena berlawanan dengan kekuatan institusi negara yang besar. Namun karena berorientasi afeksi, tindakan berbeda ini diambil dengan keyakinan tertentu yang hanya dimiliki oleh komunitas masyarakat Kampung Laut. Eksistensi dan solidaritas masyarakat dianggap lebih penting dari segalanya sehingga tindakan-tindakan yang secara formal menguntungkan ditinggal dan memilih tindakan yang dianggap sia-sia atau bahkan konyol oleh perspektif normalisme.

Karakter resisten tindakan sosial masyarakat Kampung Laut dapat dilihat dari sertifikasi hak milik. Dalam perspektif hukum positif, objek hukum yang dapat disertifikasi terbatas pada tanah atau bangunan. Sementara, perairan tidak menjadi hak privat dan menjadi otoritas institusi tertentu dari struktur pemerintahan. Sementara itu, dalam hukum adat yang diberlakukan di Kampung Laut, perairan khususnya yang berada di wilayah Segara Anakan menjadi hak privat yang bisa diwariskan kepada keturunannya. Termasuk apabila perairan tersebut akan berubah menjadi tanah atau daratan sebagai akibat dari sedimentasi. Dengan pendekatan formalistik hukum positif, gerakan sertifikasi lahan di Kampung Laut ditolak warga.

Pilihan tindakan ini dalam perspektif tindakan sosial dikategorikan rasional yang berorientasi nilai. Manfaat menolak sertifikasi yang tidak berbiaya dari pemerintah dianggap lebih bermanfaat ketimbang menerimanya. Pilihan ini sulit dipahami apabila menggunakan logika formal di mana proses sertifikasi pada umumnya berbiaya tinggi dan membutuhkan proses yang tidak sederhana. Pemeberian fasilitas sertifikasi aset privat menjadi solusi dan akan dianggap tidak rasional apabila respon yang muncul adalah penolakan.

Namun rasionalitas yang dibangun masyarakat Kampung Laut adalah 
nilai guna atau manfaat dari sertifikasi ini lebih rendah ketimbang penolakannya. Dengan melakukan penolakan, masyarakat Kampung Laut tidak kehilangan aset-asetnya terutama perairan sebagai sumber dan area utama kegiatan ekonominya. Di sisi lain, sertifikasi atas tanah dan bangunan bisa dilakukan secara mandiri yang biayanya relatif lebih kecil apabila diperbandingkan dengan aset perairan yang tidak terkover oleh hukum positif.

Secara afektif, tindakan penolakan sertifikasi aset ini memberi dampak terhadap penguatan solidaritas kelompok terutama untuk meningkatkan daya tawar terhadap institusi di luarnya. Hukum adat yang telah berlangsung turun-temurun tidak bisa dikesampingkan begitu saja oleh konstruk hukum positif. Oleh karena itu, penolakan sebagai tindakan resistensi diarahkan sebagai modal politik komunitas untuk proses advokasi menyeluruh atas hak-hak sosialnya termasuk hak ekonomi area tangkap ikan Segara Anakan.

\section{KEBERAGAMAAN SEBAGAI TINDAKAN SOSIAL MA- SYARAKAT KAMPUNG LAUT}

Karakter resisten dan laten dalam tindakan-tindakan sosial masyarakat Kampung Laut tercermin secara kolektif sebagai bagian dari identitas khas yang membedakan dengan komunitas lain. Dua karakter utama ini terepresentasi hampir pada semua tindakan-tindakan sosial, terutama yang bersifat kolektif dan massal. Proses kolektivitas tindakan sosial terbentuk, baik secara sengaja melalui mobilisasi maupun kesadaran komunal yang tersusun dari faktor-faktor pembentuknya. Dalam perspektif teori fungsionalisme, tindakan sosial merupakan respon atas stimulasi-stimulasi yang ada sehingga membentuk perilaku baru. Perilaku ini sekaligus juga akan berfungsi bagi stimulan baru yang secara beruntun akan menimbulkan respon-respon baru. ${ }^{26}$ Begitu seterusnya sehingga proses sosial dalam masyarakat terus berlangsung dan membentuk perilaku yang dinamis.

Selain contoh tindakan yang muncul secara kolektif akibat dorongandorongan fisik dan sosial seperti penolakan konservasi hutan mangrove dan penolakan sertifikasi hak-hak privat, tindakan massal yang didasarkan atas kesadaran komunal adalah tindakan keagamaan. Tidak seperti umumnya, tindakan keagamaan masyarakat Kampung Laut memiliki orientasi yang agak berbeda karena didasarkan atas pandangan-pandangan keagamaan yang khas dari komunitas pinggiran dan nelayan tradisional. ${ }^{27}$ Konstruksi keagamaan masyarakat nelayan tradisional umumnya bersifat sinkretis, yaitu mencampur ajaran-ajaran agama, baik berupa syari'at maupun akidah dengan kepercayaan-kepercayaan tradisional. Sinkretisme merupakan 
wujud spiritualitas agama nelayan yang memadukan konsep keberagamaan dengan konsep pandangan hidup komunalnya.

Pada masyarakat Kampung Laut, praktik keagamaan yang bisa dilihat dari unsur-unsur eksoterisme seperti peribadatan memiliki orientasi sebagaimana dimiliki dalam tindakan sosial lainnya. Artinya, karakter resisten dan laten juga dapat ditemui dalam praktik-praktik keagamaan masyarakat. Kondisi ini berbeda dengan praktik keagamaan pada masyarakat lainnya yang umumnya diorientasikan sebagai bentuk transendensi atas realitasrealitas empirik yang dilaluinya.

Aspek eksoteris dalam bentuk misalnya praktik peribadatan tidak lepas dari aspek-aspek esotesis yang melingkupinya. Aspek eksoteris merupakan ekspresi keberagamaan yang tampak empirik dan bisa disaksikan oleh banyak orang. Ia muncul dalam bentuk-bentuk konkret tindakan yang memiliki relevansi dengan agama tertentu misalnya shalat atau ke gereja. Adapun aspek esoteris merupakan religiusitas yang didasarkan atas keyakinan tentang keberadaan yang transendental. ${ }^{28}$

Tindakan keagamaan sebagai aspek eksoteris tidak terlepas dari konstruksi mental sebagai aspek esoterisnya. Religiusitas atau spiritualitas merupakan konstruksi pikir keagamaan yang prosesnya dipengaruhi oleh banyak faktor. Dalam konteks inilah karakter khas masyarakat Kampung Laut yang resisten dan laten cukup mengintervensi formulasi pikir yang dilakukan. Esoterisme dari perilaku keberagamaan kemudian termanifestasikan dalam dua konsep utama keagamaannya, yaitu keselamatan dan kesejahteraan.

Konsep "waras-slamet" merupakan dua idiom yang tidak bisa dipisahkan. Seseorang akan sejahtera (waras) apabila ia bisa melakukan atau menjalani kehidupan secara selamat (slamet). Situasi yang tidak sesuai dengan idealitas sosial karena proses konflik yang panjang membutuhkan kontekstualisasi konsep "waras-slamet" dalam realitas yang faktual. Kontekstualisasi "waras-slamet" dalam situasi konfliktual berbeda dengan situasi normal. Dengan ini maka pilihan-pilihan tindakan yang berkarakter resisten dan laten memiliki rasionalitas yang berorientasi nilai bagi perwujudan "sejahtera" dan "selamat" dalam kehidupan dunia dan akhirat.

Kontekstualisasi konsep "waras-slamet" inilah yang mendasari tindakan-tindakan keagamaan masyarakat Kampung Laut. Melalui pemaknaan yang berbeda dengan mainstream ini, praktik-praktik keberagamaan yang muncul terkesan berbeda dan menyimpang dengan praktik keagamaan masyarakat umumnya. Contoh sederhana misalnya dilihat dari cara berpikir tentang rizki. Baik yang beragama Islam maupun lainnya tidak memiliki 
perbedaan mendasar. Bagi masyarakat Kampung Laut, rizki diberikan Tuhan kepada mereka dalam bentuk lahan ekonomi (perairan dan daratan). Oleh karena perairan dan daratan diklaim oleh orang lain, maka merebut secara persuasif ataupun konflik dipahami sebagai bagian dari keniscayaan atau sunnatullah yang oleh karenanya bernilai ibadah.

Konsep "waras-slamet" sesungguhnya lazim berlaku pada pandangan masyarakat Jawa terhadap agama. Melalui pandangan konseptual ini, agama menjadi media bagi masyarakat untuk mencapai kebahagiaan substantif baik kehidupan dunia maupun akhirat. Secara normal, konsep "waras-slamet" akan menjadi pembimbing bagi masyarakat agama dalam menjalani kehidupannya. Kontekstualisasi konsep ini pada masyarakat jawa kemudian diturunkan pada bentuk-betuk yang lebih operasional misalnya sabar atau nrima (menerima secara ikhlas). Konsekuensi dari perilaku berbasis konsep ini adalah tindakan-tindakan yang dapat dikualifikasikan santun seperti kooperatif dan patuh.

Tindakan santun di atas secara eksplisit tidak ditemukan dalam pola keagamaan pada masyarakat kampung Laut. Hal yang terjadi justru sebaliknya, tindakan-tindakan keagamaan yang muncul mengesankan pada bentuk-bentuk yang kontraproduktif dengan fungsi agama itu sendiri. Secara fungsional, fungsi agama adalah menciptakan struktur sosial yang lebih beradab melalui produksi dan reproduksi nilai-nilai transendental. Melalui nilai inilah manusia dalam agama apapun akan mengalami titik temu. ${ }^{29}$

Bentuk-bentuk yang terkesan kontraproduktif dari tindakan keagamaan masyarakat Kampung Laut tidak lepas dari pengaruh karakter khas komunitas yang bersifat resisten dan laten. Artinya bahwa agama sebagai tindakan sosial yang bersifat massal dan komunal menjadi media sekaligus amunisi bagi masyarakat untuk mewujudkan tujuan-tujuan komunitas terlepas dari proses marginalisasi. Dengan demikian, maka agama sesungguhnya difungsikan secara politis untuk melawan gerakan-gerakan marginalisasi dari kelompok dan institusi lain di luar komunitas. Implikasi lebih lanjut dari proses politis atas agama ini adalah formulasi aspek-aspek keagamaan terutama yang bersifat eksoteris terkonstruk dalam wujud yang berbeda dengan mainstream. Wujud ini apabila dilihat secara normatif akan terjustifikasi sebagai bentuk penyimpangan agama karena berbeda dengan umumnya. Namun, oleh karena karakter khas resisten dan laten, wujud yang terkesan di luar mainstream memiliki makna yang berbeda.

Dua bentuk aspek peribadatan yang berbeda dengan mainstream adalah anjing sebagai hewan ternak dan peringatan hari besar Islam terutama nisfu sya'ban (nyadran). Keduanya berbeda dengan mainstream ekso- 
terisme Islam pada umumnya. ${ }^{30}$ Dalam pandangan masyarakat Kampung Laut, keduanya dijadikan sebagai alat untuk menunjukkan eksistensinya sebagai kelompok marginal yang memiliki tindakan-tindakan berorientasi latensi dan resistensi komunitas.

Selain dua hal di atas, hubungan antar agama masyarakat Kampung Laut relatif cair. Artinya, hubungan beberapa agama yang dianut oleh masyarakat Kampung Laut berlangsung dalam situasi sosial yang intim yang hampir tidak bisa dibedakan secara fisik antara satu penganut agama dengan penganut agama yang lain. Hal ini ditambah dengan keberadaan rumah ibadah terutama masjid dan gereja yang tidak memiliki jarak secara demarkatif. Bahkan, praktik peribadatan yang berlangsung di masjid dan gereja bisa berlangsung secara bersamaan. Ketiadaan pembeda yang demarkatif antara keduanya menjadikan hubungan keagamaan antara Islam dan Nasrani berlangsung sangat cair dan tidak menunjukkan perbedaan yang prinsipil.

Pola ini terjadi karena kohesivitas komunitas masyarakat Kampung Laut dianggap lebih penting untuk menunjukkan eksistensinya dalam situasi yang serba konfliktual. Agama menjadi pilihan untuk menunjukkan keberbedaan dengan perilaku agama mainstream karena sifatnya yang transendental, termobilisasi secara spiritual dan memiliki daya ikat kuat dalam masyarakat. Pola tindakan keagamaan yang berbeda menjadi tindakan sosial bagi masyarakat Kampung Laut untuk menunjukkan resistensi dan latensinya terhadap praktik-praktik sosial-politik kelompok atau institusi di luarnya yang berorientasi untuk memposisikannya pada posisi marginal.

\section{PENUTUP}

Perilaku keberagamaan terekspresi dari pandangan keagamaan yang konstruksinya dipengaruhi oleh kondisi lingkungan fisik dan situasi sosiologis. Bagi masyarakat Kampung Laut, kondisi fisik dan situasi sosiologis yang berbeda dengan idealitas mereka melahirkan karakter resisten dan laten. Karakter ini berpengaruh terhadap pandangan-pandangan keagamaan yang berproyeksi sebagai alat untuk melakukan perlawanan dan memunculkan fungsi-fungsi latensi dari agama.

Bagi masyarakat Kampung Laut, agama dipahami sebagai instrumen untuk keluar dari persoalan-persoalan faktual: Pertama, keterancaman lingkungan fisik yang memberi potensi kehilangan profesi dan matapencaharian. Kedua, marginalisasi komunitas oleh lembaga-lembaga pemerintah yang terlibat konflik kepemilikan atas tanah timbul di sepanjang Segara Anakan. Agama diyakini memiliki kemampuan solutif atas persoalan- 
persoalan faktual melalui metode transendensi.

Keyakinan ini kemudian mendorong masyarakat memproduksi upacara-upara ritual yang bersifat massal yang diarahkan untuk membantu masyarakat menemukan solusi atas persoalan-persoalan faktual yang dihadapi. Namun karena karakter resisten dan laten, praktik ritual keagamaan ini dikonstruk berbeda dengan mainstream. Konteks ini ditujukan untuk memberi penggambaran kepada pihak-pihak di luar komunitas bahwa masyarakat Kampung Laut memiliki eksistensi yang mandiri dan berbeda dengan opini masyarakat pada umumnya. Ritual keagamaan yang bersifat massal digunakan sebagai instrumen penyampai informasi kepada publik terkait eksistensi yang diperjuangkan.

Dengan demikian, praktik ritual keagamaan yang terkesan menyimpang sesungguhnya menjadi bagian dari perjuangan eksistensial masyarakat Kampung Laut yang mengalami marginalisasi secara politis oleh lembaga-lembaga yang terlibat konflik kepemilikan Tanah Timbul. Kesan menyimpang dikreasikan untuk tujuan memperoleh manfaat tertentu. Manfaat ini dianggap lebih besar ketimbang apabila masyarakat melakukan praktik ritual yang sama dengan keagamaan mainstream. Praktik ritual yang terkesan menyimpang ini didesain secara politis untuk memperkuat eksistensi di tengah-tengah proses marginalisasi sosial.

\section{ENDNOTES}

${ }^{1}$ Ketidakmampuan manusia mengandalkan pengetahuan dan teknologi terjadi akibat beberapa kondisi, yaitu keyakinan akan jiwa immateri, fenomena yang tidak bisa dicerna oleh akal sehat, kejadian yang sangat besar dan merusak, realitas krisis-krisis dalam hidup, sentimen kemasyarakatan, dan keyakinan akan adanya kekuatan ilahi atau wahyu. Atas kondisi-kondisi ini, masyarakat awal sejarah mencari institusi baru yang dianggap memiliki legitimasi untuk memberikan kontribusi bagi kehidupan manusia. Dadang Kahmad, Sosiologi Agama (Bandung: Rosdakarya, 2000), hlm. 23-25.

${ }^{2}$ Menurut Radcliffe Brown, agama di manapun merupakan ekspresi suatu bentuk ketergantungan pada kekuatan di luar manusia, yang dapat dikatakan sebagai kekuatan spiritual dan moral. Ekspresi penting dari rasa ketergantungan ini adalah peribadatan. Betty R. Scharf, Sosiologi Agama (Jakarta: Prenada Media, 2004), hlm. 34-36.

${ }^{3}$ Fluiditas merupakan pelenturan suatu entitas budaya pada saat ia masuk pada wilayah kebudayaan lain. Pelenturan ini membuat simbol budaya awal memetamorfosis dalam makna yang baru sekaligus membuat simbol baru. Hal ini karena manusia bukanlah makhluk mekanis yang bisa mempraktikkan apa yang diterima sebagai apa adanya dan persis. Manusia akan mendesain ulang apa yang diterimanya secara sadar ataupun tanpa sadar. Dadang Kahmad, Sosiologi Agama (Bandung: Rosdakarya, 2000), hlm. 76-77.

${ }^{4}$ Audifax, Semiotika Tuhan, Tafsir atas Pembacaan Manusia terhadap Tuhan 
(Yogyakarta: Pinus Book Publisher, 2007), hlm. 66-67.

${ }^{5}$ Cara bertindak seseorang atau komunitas terhadap sesuatu didahului oleh proses berpikir. Cara berpikir ini kemudian melahirkan sebuah konklusi atas suatu objek. Produk berpikir inilah yang kemudian menjadi paradigma dan memberi fundamen bagi pemiliknya dalam melakukan tindakan-tindakan. Bentuk tindakan disesuaikan dengan cara berpikir paradigmatis atas sesuatu yang akan dijadikan objek. Dengan demikian, tindakan seseorang atau komunitas didasarkan atas makna yang dikandung suatu objek dan dilakukan secara konsensus. George Ritzer, Sosiology, A Multiple Paradigm Science (London: Allyn and Bacon Inc, 1980), hlm. 84-85.

${ }^{6}$ Daniel L. Pals, Seven Theories of Religion (New York: Oxford University Press, 1996), hlm. 199-202.

${ }^{7}$ Stratifikasi sosial di Indonesia terbentuk dengan menggunakan empat hal dasar, yaitu ekonomi, pengetahuan, kekuasaan, dan kehormatan. Umumnya seseorang memiliki unsur lebih dari satu dari dasar pembentuk stratifikasi tersebut. Contohnya orang yang kaya umumnya juga memiliki pengetahuan yang tinggi. Semakin tinggi kepemilikan seseorang atas salah satu atau beberapa unsur pembentuk stratifikasi maka semakin tinggi pula kelas sosial di masyarakat. Sebaliknya, semakin rendah kepemilikan atas unsur pembentuk stratifikasi maka semakin rendah posisi sosialnya di masyarakat. Thomas F. O'Dea, Sosiologi Agama, Suatu Pengenalan Awal (Jakarta: Rajawali Press, 1996), hlm. 109-111.

${ }^{8}$ Marginalisasi merupakan proses sosial yang melibatkan beberapa orang atau kelompok dalam satu konteks tertentu. Marginalisasi dilakukan melalui penggambaran buruk seseorang atau komunitas terhadap orang atau komunitas lain. Praktik marginalisasi menggunakan eufemisme (penghalusan makna), disfemisme (pengasaran), dan labelisasi. Eriyanto, Analisis Wacana, Pengantar Analisis Teks Media (Yogyakarta: LKiS, 2009), hlm. 124-126.

${ }_{9}$ Pendangkalan Segara Anakan membuat masyarakat Kampung Laut mencari alternatif matapencaharian baru sebagai antisipasi hilangnya area tangkap. Salah satu bentuk alternatif itu adalah mengelola tanah timbul hasil sedimentasi sungai Citanduy dan Cimeneng. Persoalannya adalah tanah timbul tersebut disengketakan oleh tiga lembaga negara. Masyarakat mengelola tanah timbul semata-mata subsistensi ekonomi namun kemudian dilabeli sebagai perambah liar, penyerobot tanah, dan perusak ekosistem. Ahmad Muttaqin, "Alih Profesi Masyarakat Kampung Laut", makalah disampaikan pada Jambore Nasional Forum Warga di Makassar tahun 2008.

10 George Ritzer, Sociologi, A Multiple Paradigm Science (London: Allyn and Bacon Inc, 1980), hlm. 53.

11 SP. Turner, The Cambridge Companion to Weber (New York: Cambridge University, 2000), hlm. 15.

12 Ibid., hlm. 75.

${ }^{13}$ David Lee dan Howard Newby, The Problem of Sociology (London: Hutchinson \& Co. Publisher Ltd, 1984), hIm. 177-179.

${ }^{14}$ Doyle Paul Johnson, Teori Sosiologi Klasik dan Modern, Alih Bahasa MZ. Lawang (Jakarta: Gramedia, 1988), hlm. 113.

${ }^{15}$ Misrepresentasi adalah penggambaran yang tidak sebenarnya dengan yang sesungguhnya. Tujuan representasi adalah memposisikan objek pada situasi yang memungkinkan pihak-pihak lain memiliki penilaian yang buruk. Melalui penilaian bu- 
ruk ini, objek representasi akan mendapatkan perlakuan, respon, dan penilaian yang negatif tindakan dan sikap yang diambilnya. Praktik miskomunikasi umum berlaku di pemberitaan dengan 4 bentuk utama, yaitu ekskomunikasi, eksklusi, marginalisasi, dan delegitimasi. Masing-masing bertujuan sama namun dari sisi pendekatan sedikit berbeda. Eriyanto, Analisis Wacana, Pengantar Analisis Teks Media (Yogyakarta: LKiS, 2001), hlm. 120-125.

${ }^{16}$ Contoh praktik marginalisasi adalah pemanfaatan lahan tanah timbul di Kampung Laut untuk kegiatan pertanian dan perikanan. Pemanfaatan ini sesungguhnya tidak merugikan siapapun karena berada di sepanjang aliran sungai. Namun keberadaan warga Kampung Laut yang dimarginalisasi oleh kelompok-kelompok yang berkonflik menjadikan pemanfaatan tanah timbul menjadi buruk. Kegiatan pemanfaatan lahan kemudian dibahasakan sebagai penyerobotan lahan atau perambahan liar lahan pertanian. Bahasa yang berkonotasi buruk ini kemudian memberi asumsi secara umum bagi publik bahwa warga Kampung Laut adalah kelompok pelanggar hukum. Ibid., hlm. 126-127.

${ }^{17}$ Istilah yang sering digunakan untuk menggambarkan keberbedaan sosial dengan mainstream adalah patologi sosial. Indikator seseorang atau kelompok dianggap patologis adalah diferentiatif dan deviatif dengan mainstream umum. Apabila seseorang atau kelompok bertindak, berperilaku, dan bersikap berbeda atau menyimpang dari kategori-kategori umum maka ia akan diklasifikasikan sebagai orang yang patologis atau sosiapatik. Patologi bersifat lintas kebudayaan, artinya seseorang atau komunitas hanya akan dianggap patologis apabila ia masuk dalam konstruk budaya yang berbeda dengan situasi lokal sosialnya. Sebagai contoh, pemulung dianggap patologis apabila ia masuk dalam kebudayaan masyarakat berprofesi formal. la akan dianggap normal selama berada pada kelompok pemulung sebagai komunitas lokalnya. Kartini Kartono, Patologi Sosial (Jakarta: Raja Grafindo, 2009), hlm. 11-13.

${ }^{18}$ Asumsi teoretis fungsionalisme adalah bahwa tindakan sosial muncul apabila dianggap bermanfaat bagi pelakunya. Tindakan tersebut akan hilang seiring dengan nilai kemanfaatan yang berkurang. Tindakan manusia senantiasa berada dalam keseimbangan. Kemampuan untuk menstrukturkan diri bersifat alamiah dan merupakan proses dinamis. Konflik yang terjadi bersifat transisional dan akan kembali menemukan keseimbangan baru pada saat masing-masing fungsi yang ada dalam masyarakat terisi oleh individu-individu yang terdistribusi dalam fungsi-fungsi yang deferentiatif. Doyle Paul Johnson, Teori Sosiologi Klasik dan Modern, Alih Bahasa MZ. Lawang (Jakarta: Gramedia, 1988), hlm. 131-134.

${ }_{19}$ Pembentukan perilaku sosial secara sosiologis berlangsung dalam empat model, yaitu identifikasi, imitasi, sugesti, dan simpati. Masing-masing merupakan klasifikasi yang bersifat tidak linier. Individu atau kelompok memiliki watak perilaku yang didasarkan atas salah satu metode tersebut. Namun demikian, metode-metode tersebut hanya berlaku pada masyarakat yang memiliki karakter transformatif di mana pengalaman-pengalamannya didasarkan atas proses-proses yang bersifat normal. Pada masyarakat konfliktual, pola perilaku sosialnya lebih bersifat resisten. Abu Ahmadi, Psikologi Sosial (Jakarta: Rineka Cipta, 1999), hlm. 57-61.

${ }^{20}$ Relasi-kuasa berpengaruh terhadap konstruksi sosiologis suatu masyarakat. Hal ini karena relasi kuasa melahirkan hubungan yang tidak seimbang antara kelompok dominan dan terdominasi. Kelompok dominan memaksakan segala sesuatu yang di- 
milikinya untuk dilakukan oleh kelompok terdominasi, termasuk penilaian tentang baik atau buruk. Kelompok terdominasi dipaksa untuk melakukan sesuatu yang menurut kelompok dominan sebagai baik. Kondisi ini yang dalam istilah Bourdieu sebagai kekerasan simbolik, yaitu penaklukkan ideologis kelompok-kelompok sosial. Pierre Bourdieu, In Other Words, Essays Towards a Reflexive Sociology (Cambridge: Polity Press, 1990), hlm. 122-124.

${ }^{21}$ Pemikiran filsafat modern tentang masyarakat terbelah menjadi 2 (dua) yaitu terciptanya kehidupan masyarakat berdasarkan hasil persetujuan dan konsensus umum. Aliran lain berpendirian bahwa ikatan dan tata kehidupan masyarakat didasarkan atas kekuasaan dan paksaan golongan tertentu dan penundukan terhadap golongan lain. Terminologi marginalisasi didasarkan atas aliran pemikiran sosial yang kedua bahwa ia merupakan praktik sosial-politik yang menekankan adanya dominasi kekuasaan. Ralf Dahrendorf, Konflik dan Konflik dalam Masyarakat Industri (Jakarta: Rajawali Press, 1986), hlm. 191-194.

22 Teori fungsionalisme struktural memiliki asumsi bahwa masyarakat memiliki kemampuan untuk menstrukturkan diri. Perubahan dalam masyarakat merupakan keniscayaan yang pasti terjadi sepanjang masyarakat memiliki kebutuhan yang terus berubah dan bertambah. Proses perubahan bersifat evolutif melalui penyesuaianpenyesuaian dan akan menemukan bentuk permanennya saat masing-masing anggota memerankan fungsi sosialnya secara diferentiatif. Proses transisi ini yang lazim disebut dengan konflik sosial. Jonathan $\mathrm{H}$. Turner dan Alexandra Maryanski, Fungsionalisme (Yogyakarta: Pustaka Pelajar, 2010), hlm. 167-169.

${ }^{23}$ Contoh fungsi manifes dan laten adalah praktik pendidikan. Fungsi manifes dari pendidikan adalah menciptakan generasi edukatif yang memiliki kemampuan pegetahuan dan praktis yang bermanfaat bagi proses pembangunan nasional. Peserta pendidikan diharapkan menjadi pioner bagi penyelenggaraan pembangunan. Namun secara bersamaan, tenaga-tenaga terdidik ini juga memiliki kemampuan untuk melakukan tindakan-tindakan yang melanggar hukum secara lebih canggih. Praktik korupsi mutakhir adalah salah satu hasil dari proses pendidikan. Semakin tinggi pendidikan seseorang, kemampuan korupsinya juga semakin modern. Frank J. Miflen dan Sydney C. Miflen, Sosiologi Pendidikan (Bandung: Transito, 1986), hlm. 453-437.

${ }^{24}$ Menurut cerita rakyat yang sampai sekarang masih dipercaya kebenarannya oleh masyarakat setempat, penduduk asli Kampung Laut adalah anak keturunan dari para prajurit Mataram. Para prajurit Mataram pada waktu itu datang ke daerah Kampung Laut untuk mengamankan daerah perairan Segara Anakan dari gangguan bajak laut orang Portugis. Para prajurit itu dipimpin oleh empat orang wiratamtama, yaitu Jaga Playa, Jaga Praya, Jaga Resmi, dan Jaga Laut. Berkat kesaktian para wiratamtama itu maka perairan Cilacap dan Segara Anakan akhirnya aman, bebas dari gangguan bajak laut. Setelah keadaan aman, ternyata para wiratamtama dan anak buahnya itu tidak mau kembali ke pusat kerajaan Mataram, melainkan tetap tinggal di kawasan Cilacap dan sekitarnya. Jaga Playa dan Jaga Praya bermukim di daerah yang sekarang disebut Klapalima, sementara itu Jaga Resmi dan Jaga Laut memilih tinggal di Pulau Nusakambangan. Jaga Resmi bermukim di daerah yang kini disebut Legok Pari, sedangkan Jaga Laut bertempat tinggal di Gebang Kuning atau yang sekarang lebih dikenal dengan nama Kembang Kuning.

${ }^{25}$ Alokasi untuk kegiatan ekonomi produktif dalam kerangka pemberdayaan tahun 
2012 di Kampung Laut mencapai Rp. 2 Milyar yang diakumulasi dari DAK dan APBD Kabupaten. Dana ini akan bertambah besar apabila digabung dengan dana yang dialokasikan langsung oleh pemerintah pusat melalui APBN. Leading sector kegiatan ini adalah Dinas Kelautan dan Perikanan, Dinas Pertanian, Dinas PU dan Cipta Karya, dan Dinas Koperasi dan UMKM. Angka semakin fantastis kalau diakumulasi dengan dana-dana dari funding luar negeri yang juga menggunakan isu tentang pemberdayaan ekonomi yang titik masuknya adalah warga sebagai perambah liar hutan mangrove atau tanah timbul. Data Forum Indonesia untuk Transparansi (FITRA) Kabupaten Cilacap.

${ }^{26}$ Ian Craib, Teori-Teori Sosial Modern, dari Parsons sampai Habermas (Jakarta: Raja Grafindo, 1994), hlm. 71-73.

${ }^{27}$ Orientasi umum setiap tindakan sosial masyarakat nelayan adalah bertahan hidup dan bekerja. Setiap saat, keluarga nelayan mengalami rasa terancam dalam rangka memenuhi kebutuhan pokok. Tindakan sosial yang dilakukan termasuk agama sesungguhnya didasarkan untuk menciptakan rasa aman dari keterancaman tersebut. Agama menjadi lebih spesial karena masyarakat memiliki padangan yang tidak hanya profan seperti sandang, pangan, dan papan, tetapi juga punya pandangan-pandangan yang jauh ke depan. Proyeksi keagamaan ini yang lalu menjadi dasar nelayan untuk mendapatkan keamanan dalam hidup. Kusnadi, Konflik Sosial Nelayan, Kemiskinan dan Perebuta Sumberdaya Perikanan (Yogyakarta: LKiS, 2002), hlm. 12-13.

${ }^{28}$ Amin Abdullah, Studi Agama, Normativitas atau Historisitas ?, Cet. IV (Yogyakarta: Pustaka Pelajar, 2004), hlm. 12-13.

${ }^{29}$ Kemunculan agama secara sosiologis memiliki pola yang sama. Agama dimunculkan saat manusia mengalami keterbatasan secara teknologis dan pengetahuan di mana keduanya diandalkan untuk menyelesaikan persoalan kemanusiaan. Namun pada titik tertentu, pengetahuan dan teknologi mengalami keterbatasan sehingga manusia mencari kekuatan lain di luar keduanya. Dari proses inilah kemudian agama muncul. Metode yang ditawarkan oleh agama adalah transendensi, yaitu pola pikir yang mengatasi empirisisme. Metode solutif agama tidak faktual sebagaimana pengetahuan dan teknologi, tetapi abstrak. Nilai abstrak inilah yang lalu menjadi dasar bagi produksi dan reproduksi yang berorientasi pada penguatan moral dan spiritual. Dadang Kahmad, Sosiologi Agama (Bandung: Rosda, 2000), hlm. 26-28.

${ }^{30}$ Secara normatif, anjing adalah hewan yang dikategorikan sebagai najis mughaladzah. Oleh karenanya banyak umat Islam menghindari memelihara anjing sebagai hewan ternak. Adapun nyadran umumnya digunakan oleh masyarakat Islam sebagai media untuk membangun silaturrahim dengan keluarga melalui ziarah kubur kepada keluarga yang telah meninggal. Bagi warga Kampung Laut, nyadran digunakan untuk berhubungan langsung dengan "penguasa" pantai selatan sebagai penyedia rezeki di lautan. Prosesi ini dilakukan dengan upacara besar melalui tindakan-tidakan keagamaan yang sinkretis.

\section{DAFTAR PUSTAKA}

Abdullah, Amin. 2004. Studi Agama, Normativitas atau Historisitas?, Cet. IV. Yogyakarta: Pustaka Pelajar.

Ahmadi, Abu. 1991. Psikologi sosial. Jakarta: Rineka Cipta. 
Ardianto, Elvinaro dan Q-Anees, Bambang. 2007. Filsafat Ilmu Komunikasi. Bandung: Simbiosa Rekatama Media.

Berger, Peter L dan Luckman, Thomas. 1990. Tafsir Sosial atas Kenyataan, Risalah tentang Sosiologi Pengetahuan. Jakarta: LP3ES.

Bourdieu, Pierre. 1990. In Other Words, Essays Towards a reflexive Sociology. Cambridge: Polity Press.

Craib, Ian. 1994. Teori-Teori Sosial Modern, dari Parsons sampai Habermas. Jakarta: Raja Grafindo.

Dahrendorf, Ralf. 1986. Konflik dan Konflik dalam Masyarakat Industri. Jakarta: Rajawali Press.

Erikson, Erik H. 1968. Identity, Youth and Crisis. New York: W. W. Norton Company. Eriyanto. 2009. Analisis Wacana, Pengantar Analisis Teks Media. Yogyakarta: LKiS. Fromm, Erich. 1947. Man for Himself, An Inquiry Into the Philosophy of Ethics. ttp: tth.

Johnson, Doyle Paul. 1988. Teori Sosiologi Klasik dan Modern, Alih Bahasa MZ. Lawang. Jakarta: Gramedia.

Kahmad, Dadang. 2000. Sosiologi Agama. Bandung: Rosdakarya.

Kusnadi. 2002. Konflik Sosial Nelayan, Kemiskinan dan Perebuta Sumberdaya Perikanan. Yogyakarta: LKiS.

Lee, David dan Newby, Howard. 1984. The Problem of Sociology. London: Hutchinson \& Co. Publisher Ltd.

Miflen, Frank J. dan Miflen, Sydney C. 1986. Sosiologi Pendidikan. Bandung: Transito.

Muttaqin, Ahmad. 2008. "Alih Profesi Masyarakat Kampung Laut", makalah disampaikan pada Jambore Nasional Forum Warga di Makassar 2008.

Nugroho, Heru. 2001. Menumbuhkan Ide-Ide Kritis. Yogyakarta: Pustaka Pelajar.

O’Dea, Thomas F. 1996. Sosiologi Agama, Suatu Pengenalan Awal. Jakarta: Rajawali Press.

Pals, Daniel L. 1996. Seven Teories of Religion. New York: Oxford University Press.

Pusat Studi Asia Pasifik (PSAP) UGM Yogyakarta "Keanekaragaman Hayati Segara Anakan", Laporan Penelitian tahun 2001-2001.

Rahman, Agus Abdul. 2013. Psikologi Sosial, Integrasi Pengetahuan wahyu dan Pengetahuan Empirik. Jakarta: Raja Grafindo.

Ritzer, George. 1980. Sosiology, A Multiple Paradigm Science. London: Allyn and Bacon Inc.

Scharf, Betty R. 2004. Sosiologi Agama. Jakarta: Prenada Media.

Soekanto, Soerjono. 2002. Sosiologi Suatu Pengantar. Jakarta: Raja Grafindo.

Stryker, Sheldon. 1980. Symbolic Interactionism, A Structural Version. California: Benjamin Cummings.

Taylor, SJ dan R Bogdan. 1984. Introduction to Qualitative Research Methods, The Search Meanings, Second Edition. Toronto: John Miley and Sons.

Turner, Jonathan H. dan Maryanski, Alexandra. 2010. Fungsionalisme. Yogyakarta: 
Ahmad Muttaqin: Pola Keberagamaan Masyarakat Marginal

Pustaka Pelajar.

Turner, SP. 2000. The Cambridge Companion to Weber. New York: Cambridge University.

West, Richard dan Turner, Lynn H. 2008. Pengantar teori Komunikasi: Analisis dan Aplikasi, Buku 1 edisi ke-3, Terjemahan Maria Natalia Damayanti Maer. Jakarta: Salemba Humanika. 